\title{
Community Projects to Enhance the Students' English Learning Process of Access Class Site Surakarta, Indonesia
}

\author{
Muhammad Taufiq al Makmun ${ }^{*}$ and Ardianna Nuraeni \\ English Department, Faculty of Cultural Sciences, Universitas Sebelas Maret, J1. Ir. Sutami No. 36A, \\ Surakarta 57126, Indonesia
}

\begin{abstract}
This paper aims at (i) describing the steps and functions of and (ii) explaining the effectiveness of the service learning method through two community projects to enhance the English learning and leadership skills of the university students of Access Microscholarship Program site Surakarta conducted in Universitas Sebelas Maret (UNS). The theme of the community projects were "helping senior citizens" and "clean the environment campaign". The description of the steps and the functions of the service learning method was obtained by doing a class observation to 20 students enrolling Access Class. Class assessment, questionnaire distribution, and indepth interview to the students were conducted to see the effectiveness of the method to enhance their learning process. Each community project was done by employing these steps: preparing idea; determining and surveying site; conducting community project; preparing report for a poster presentation; and oral poster presentation. The last step was used to assess the students' English skills. The results show that the two community projects are effective to improve not only the students' English skills but also their social awareness and leadership skills. Most of the students have experienced service learning method through community project as a new fun way to learn language.
\end{abstract}

Keywords: Community project, english learning, leadership skill, service learning, social awareness

\section{Introduction}

Issue in English teaching recently includes the idea of service learning as one of methods in teaching. Considering the need of social awareness of students as part of the teaching goal, service learning is seen as an effective method. This method is like a double-edges sword, an English class which employs service learning is aimed at both achieving the main teaching goal-students' understanding on certain material or English skills- and community awareness as well, it may impact further on students' leadership skill and critical thinking

\footnotetext{
${ }^{*}$ Corresponding author: muhammadtaufiq@staff.uns.ac.id
} 
through the rising sense of social care because "service-learning translates theory into practice, statistics into real people, and ideas into action" [1].

Service learning is a teaching method which involves community activities. Social activities are conducted in line with the material prepared in class. Social activities are community projects done by the students based on determined theme to enhance the students' learning process. This method provides opportunity for the students to learn while conducting real activities in the society. Therefore, students do not only gain knowledge or skill on English language but also obtain social experience. They learn theories and are able to practice their knowledge accordingly within the society. By doing so, it creates a learning environment which connects to the their future life, society. Meuers highlights Billig's research on K-12 School-Based Service-Learning in 2000 which suggests that "service-learning impacts the ability of students to interact with culturally diverse groups, increases empathy, and trust" [2].

Service learning could be the answer of degrading social awareness of the millenials. Millenial generation is more connected to media, technology and less direct contact to the life of community since they are interacting more through social media and are gadgetminded. If their process of learning is also exclusively conducted away from the community or social life it will indeed encourage the missing sense of social awareness. That is why service learning is seen as a learning tool, as a bridge, to empower students to see and solve problems in their own communities, where students could learn about a particular issue or problem, then "figure out how to take action in a positive way" [3]. Unlike social media which is more interesting to the millenials for them to learn it by themselves, social awareness needs encouragement to be created.

Looking at the above considerations, service learning has significant aspects to be applied, in this case in English class. Language as a communication tool is easily connected to any social issue. Integrated learning in language class has adopted the the idea of using the actual issue in the society e.g. as themes presented in language skills: reading, listening, writing and speaking. The important missing part is, however, the interaction with the society itself during the process of learning. Applying service learning in their English language learning equips students not only with vocabularies and knowledge related with the given issues but also with the deeper awareness regarding the issues.

Issues on senior citizen and environment are two of global major social issues today. Inserting the two theme in language learning will raise the students' understanding on recent social problem. These two subject matters are also themes on reading text used in Access class, i.e. "In Focus" book [4]. The students were obliged to do community projects on "Helping Senior Citizens" in the first semester and "Clean the Environment" in the second semester. The idea is to send them to meet the society bringing the issues they have learned to be transformed into real activities to empower the society in a community project conducted in group. More specifically, "students can deepen their understanding of individual leadership, systemic change, and social responsibility in the context of a local, national, and global multicultural society" [1]. They needed to set the idea of the activities, and execute it within the society by doing a "Direct Service, i.e. a type of service engaging students face-to-face with people" [1]. This type of service is the one done by the students of Access class. Once they have done the activities they need to prepare a group poster presentation as oral presentation test in their English class.

This paper discusses the best practice of service learning in Access English class for university students conducted throughout community projects in a way it enhance the students English skill and leadership. Access Micro-scholarship Program is an English class project funded by the US Government throughout its representative in Indonesia, RELO, the US Embassy in Jakarta. The project has been started since 2016 to be held for four semesters in five sites Indonesia including one in Universitas Sebelas Maret, Solo. It is 
intended to encourage the students to learn English, enrich cultural insight, and develop leadership. There are two classes for high school level and one for university students. This paper focusses on the class for university students, for the "Access English class" will be used as a term to point this class. The two writers of this paper are the teachers of the class who found service learning as a new teaching methodand are interested to see its effectiveness in English learning class.

\section{Methodology}

This study belongs to a descriptive qualitative research since the analysis was done by describing the real condition of both in-class and out-class Access class activities experienced by the 20 university students enrolling the Access Program. The students becoming the subject of this study are those studying formally in four different universities in Surakarta, i.e. Universitas Sebelas Maret (UNS), IAIN Surakarta (State Institute for Islamic Studies), ABA Pignatelli, and Universitas Surakarta (UNSA), who have been joining the Access English program for two semesters. Those students formally enroll English major in their universities. During the two semesters they had conducted two community projects "helping senior citizens" and "clean the environment campaign", as have been written in the course syllabus.

The data needed to answer the mentioned problems of this study were gained from methods of class assessment, questionnaire distribution, and in-depth interview. The first method, class assessment, was done by conducting direct observation and by recording on the poster presentation process to find out the students' English skill, of which the assessment was referred to an available grading rubric comprising assessment of linguistic aspects of pronunciation, grammar features, vocabulary. Other non-linguistic aspects, such as completeness of the presentation content, ways to deliver the content, physical aspect and personality, and ways to handle questions, also become points to assess. Questionnaire was also delivered to them to gain initial information about their two Access community projects. It covers questions about their step-by-step activities, their poster presentation used as their media to report the projects, lessons and values they could learn and get from the projects, as well as their self-evaluation on social awareness and leadership skill. The last method, in-depth interview, was then done by inviting each student to the session where they were asked some further questions dealing with the questionnaire's results. The employed questions were particularly focused on the effectiveness of the community projects to their service learning experience and to their English learning process.

To measure the effectiveness, the writers use the gained data to be analyzed to see how the goals and functions of each step of the community project could be achieved. There are five stages of Service Learning presented, i.e. (i) preparing an idea (of service learning activity); (ii) determining and surveying the site to do community projects; (iii) conducting community projects; (iv) preparing a report for poster presentation; and (v) oral poster presentation. "Reflection" functioning the most important stage of every service learning activity is simultaniously presented within the stage of preparing poster contents.

\section{Discussion}

This section describes the steps of the process of conducting two community projects "helping senior citizens" and "clean the environment campaign". There are five steps employed by the Access students, which can be briefly explained as follows. 


\subsection{Step 1: Preparing an idea}

Before working in a group of five to discuss a sub-topic relevant to the main given topic, the Access students were encouraged to understand the project they would conduct. Defining and understanding the concept are very important to lead the students' ideas to stick on the goal of the project. In the first project, for example, the students were firstly asked the meaning of "senior citizens" and the importance of doing a project to "help senior citizens", elicited their answers and discussed them in order to easily bring them to determine the sub-topic of their community project activity. Then they had a discussion to choose the best sub-topic, the target of senior citizens they were going to help, and also the specific activities they set to help the targets. Same stages were also done by the students in preparing the second project "clean the environment campaign". Activity of preparing ideas functions to encourage them to express their opinions and to trigger their awareness to some social issues within their surrounding neighbourhood. Within this step of preparing ideas, some students said that they could learnt how to plan and run a program, how to respect other group members' opinions and how to distribute equal jobs for each member of the group, while some others admitted that they became more confident and more active in taking the right decision for their group, including anticipating some unexpected things that might happen when the project is running. The results of their discussion can be summarized below.

Table 1. Ideas of community projects elicitated by each group of Access students

\begin{tabular}{|l|l|}
\hline \multicolumn{1}{|c|}{ Helping Senior Citizens } & $\begin{array}{l}\text { Clean the Environment Campaign } \\
\text { (at Solo Car Free Day/CFD) }\end{array}$ \\
\hline $\begin{array}{l}\text { i) Making conversation with the senior } \\
\text { citizens, giving them somedaily needs, } \\
\text { cleaning their place, and checking their } \\
\text { health condition. }\end{array}$ & $\begin{array}{l}\text { Making a photo booth, inviting the CFD } \\
\text { goers to come to their stand, explaining } \\
\text { them about their campaign and giving } \\
\text { flowers as souvenirs made of straws and } \\
\text { used newspapers. }\end{array}$ \\
\hline $\begin{array}{l}\text { ii) Helpingsenior citizens to sell their trade } \\
\text { products such as brushes, buckets, } \\
\text { feather dusters, etc. and giving them } \\
\text { some daily needs. }\end{array}$ & $\begin{array}{l}\text { Making their own bracelets and posters, } \\
\text { preparing some big trash bags, walking } \\
\text { along the area of CFD to ask people to } \\
\text { put their trash into the trash bags, and } \\
\text { giving them the bracelets as a sign that } \\
\text { they have supported the campaign. }\end{array}$ \\
\hline $\begin{array}{l}\text { iii) Helping a shoe repairman doing his job } \\
\text { such as putting glue on shoes, stitching } \\
\text { shoes, cleaning the shoes, etc. and giving } \\
\text { him some daily needs. }\end{array}$ & $\begin{array}{l}\text { iii) } \\
\text { Running a petition campaign by asking } \\
\text { CFD goers to write their signature, } \\
\text { giving stickers as a souvenir and doing a } \\
\text { real action by collecting organic and } \\
\text { non-organic rubbish in a separated trash } \\
\text { bags. }\end{array}$ \\
\hline $\begin{array}{l}\text { iv) Sharing life stories and problems, telling } \\
\text { jokes to the senior citizens, giving them } \\
\text { some primary needs, and helping them } \\
\text { sell their products (home equipments) }\end{array}$ & \begin{tabular}{l} 
iv) $\begin{array}{l}\text { Conducting a workshop (for children) } \\
\text { on coloring paintings made from } \\
\text { porridge used newspaper. }\end{array}$ \\
\hline
\end{tabular} \\
\hline
\end{tabular}

\subsection{Step 2: Determining and surveying the site to do the project}

This step has a purpose to involve the students in a real small-scale research, in which they surveyed the target of senior citizens by looking into the condition of the senior citizens and interviewing them. Some data of the targets' identity, address, house condition, and job 
were gained, which then led them to decide whether the students would help them or not. After decision had been made, another visit was done by the students to make an agreement on the day when they did their helping activities. Two interesting results found are that one group decided to look for another target since they witnessed the first target's house was already in a good condition, which is they actually misled in interpreting the theme of "helping senior citizens", while another group had a challenge to change their targets twice due to the rejection of the olds to be helped. This case is, in fact, giving them an experience of how to solve unexpected problems together patiently.

In doing the project of "clean the environment campaign", the students did not do any site survey since the place to do the project has already been determined, i.e. along the street of Slamet Riyadi where the Car Free Day (CFD) takes place every Sunday morning, but they had a chance to discuss somestrategic spots to execute their plans first before blending themselves with the CFD goers. In the preparation session, however, the students did various ways to prepare anddetermine their final plans by watching videos, making flowers from straws, making bracelets, and designing stickers (See Figure 1 to Figure 4). These activities do give a chance for the students to spell out their own ideas, adjust plans, and communicate their intentions, as those are the essence of leadership skills [5].

Two key points in this step are to enhance the ability of the students to gather information, which is the basic of research skill, and to provide them an opportunity to discuss and execute their ideas which is the essence of leadership.

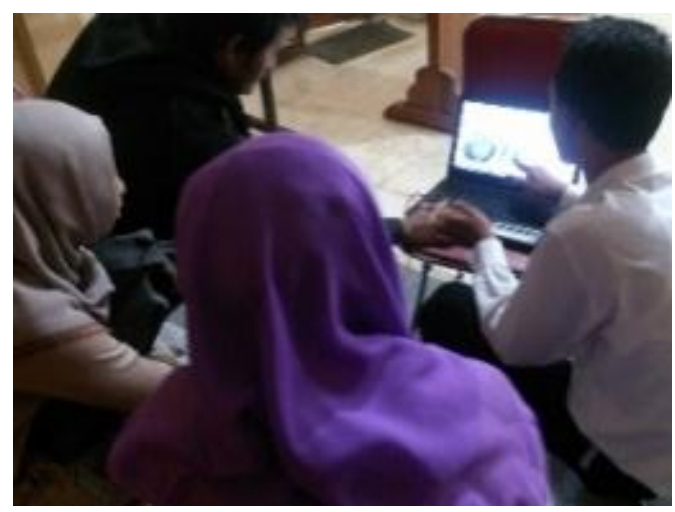

Fig. 1. Watching video.

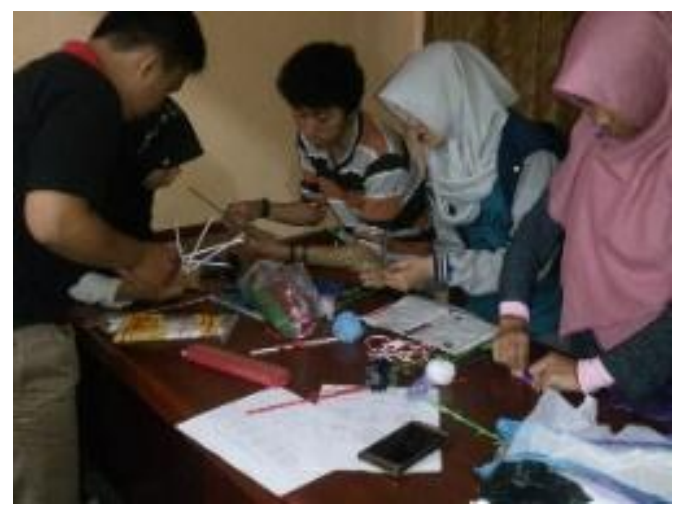

Fig. 2. Making flowers from straws. 


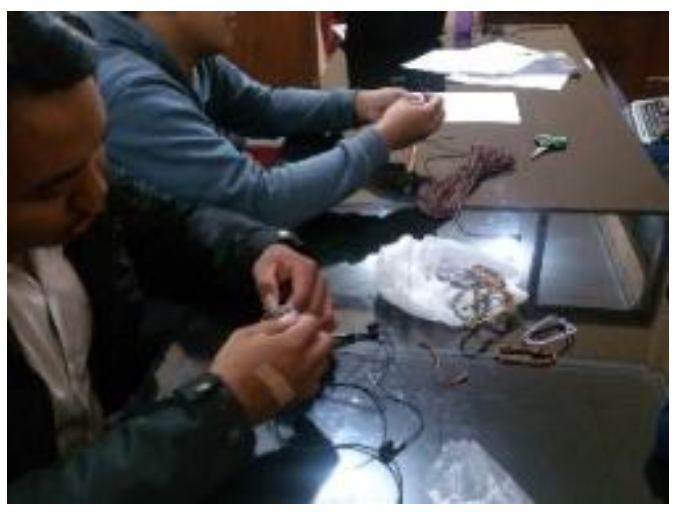

Fig. 3. Making bracelets.

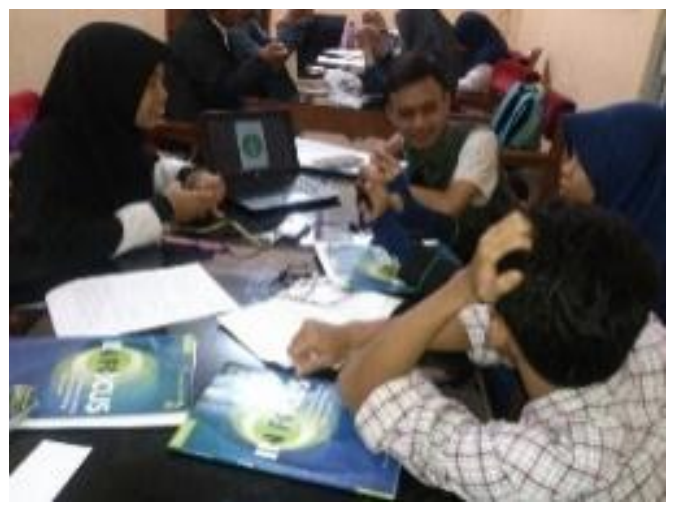

Fig. 4. Designing stickers.

\subsection{Step 3: Conducting the community project}

Executing the plans are the most awaiting moment for the students since they would be facing a real dynamic condition of the society directly, where unpredictable things are possible to happen. This third step functions to implement the students' planning, in which the actual experience of service learning happens and where the students translate ideas into action. When meeting the community directly, they not only did activities as planned but also practised note-taking of their problems and solutions and to record their activities through pictures. During the field activities, some of them found a gap between what had been planned and what were happening on the service, as they found that not all members of the society gave positive responces as what they firstly expected. What the students face in the environmental campaign is probably a good example to explain such a gap. A group working on inviting the CFD goers to come to their photo booth and explaining about how to keep the environment clean, for instance, firstly found difficulties to persuade the people to come closer to listen to their program, eventhough they were offered straw-flower souvenirs. That problem made the group think of the solution, i.e. collaborating with another group running a petition campaign by asking those who had given their signatures on the petition to visit to the photo booth. This shows how the students' ability to work well with others, where communication skill is hoped to develop [6]. 


\subsection{Step 4: Preparing the report for a poster presentation}

As designed in the syllabus, the results of community project activities needs to be reported orally in English in the form of poster presentation. In other words, the students have to sit together (within their group) to store and highlight information of what they have got during the project, to determine the content of their poster, to share duties of poster design project, and to assign each individual's job for presentation. These activities purpose to accommodate their creativity, as well as to facilitate the students to speak up more about their original ideas freely in English. Competences of evaluating and writing a report in English are also trained. In addition, "Reflection Following Service", a term used to refer to a process in which students can start to see the depth and the meaning of their engangement and to change their emotional knowledge towards the service [3], is thoroughly discussed in this step of poster preparation.

Through an interview conducted during the students' poster preparation, some interesting findings towards the students' reflection after doing the projects were revealed. Questions employed are those addressing their affective experience, such as How do you feel after doing the projects? In what ways the project change you personally in the future? Does it improve your social awareness and leadership skill? What values do you get from the community project? Do you continue doing the activities until today?

To see their reflection, look into some of the students' words quoting their reflection on "Helping Senior Citizens" project below.

i) "By conducting such projects, I learnt that I should be grateful. I have to be a generous person because it is beautiful to help others." (Ajeng - UNS)

ii) "Helping someone who needed our help is valuable things and I realize that I was a lucky person" (Rizki - UNSA)

iii) "We have to be grateful with what we have and do any kind of activity sincerely. Don't too much complain" (Atika - UNS)

iv) "We learnt how to share what we have, the beauty of sharing. Our awareness grown after we look around us and surrounding, now we know that there are many people need to be cared, especially the seniors." (Himawan - IAIN)

v) "I learnt that I have to be grateful in all situations. This project makes me to be a grateful person and care to others." (Fiska - UNS)

In addition, questions relating to the "Clean our environment campaign" project result the following reflections.

i) "We have to be aware of our environment. Start with small thing that will give a big impact to the environment. If I see trash not in the trash bag I will take it and put it in the trash bag" (Imam - IAIN)

ii) "Through this program, I knew that from the rubbish we can make something more valuable. I can do little things for better environment." (Susilo Adi - ABA Pignatelli)

iii) "I can learn that we should not be an ignorant person. We should take care of our Earth even from the smallest thing." (Dindha - UNS)

iv) "We realize how important the dustman in our environment and the rubbish will be our problem if we couldn't manage it." (Atika - UNS)

v) "We have to improve our awareness, especially in our environment. We live in this Earth, the Earth gives us what we need, so it is our obligation to keep our Earth to be good." (Abpas - UNS)

"Reflection activities provide the bridge between the community service activities and the educational content of the course" [7]. From some of the students' quotes above, it is obvious that they were able to connect between their past actions that had been done or achieved and their future actions. Let's take Imam's statements as an example. His words show that the campaign project has been successful in making him more aware of his environment, and he promises himself to take a real action in the future, throwing rubbish 
in the trash bag. It clearly shows that Imam is able to foster his civic responsibility and this proves that "critical reflection", a process of looking back on the implications of actions taken determining what has been gained and connecting to future actions within larger social context [8] is successfully performed by him. The following graph summarizes the values the students got from doing the community project activities.

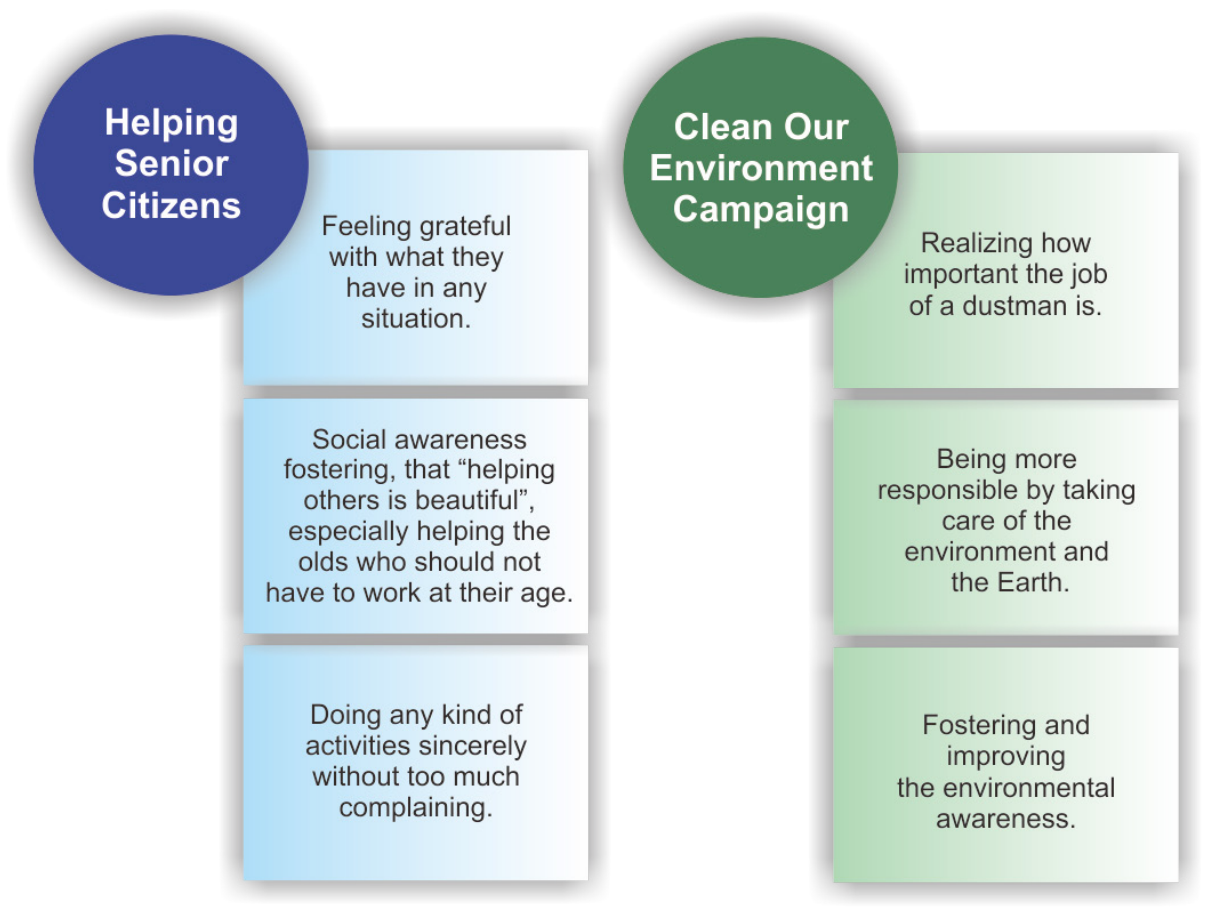

Fig. 5. Values of doing access community projects.

\subsection{Step 5: Oral poster presentation}

This step gives the students an opportunity to share their experience through a presentation using a poster containing documented information of the community projects. The presentations were conducted in English. It is aimed at fostering the students' English oral skill as well as presentation skill. The presentations were graded as the final test of each semester as designed in the syllabus. The assessment was done based on the following presentation rubrics.

It is interesting to observe that this final step shows the effectiveness of the community projects to enhance the students' English oral skill in a presentation. Most of them were confident to present their part not only due to their well-preparation but also their attachment to the service they had experienced. It is shown by the expression of their emotional attachment after helping senior citizens and statement of being more responsible to their environment. In an English presentation for second language learners, students practice both on how to speak English and voice their ideas at the same time. Personal experience during the service in the community projects helped them to construct unique ideas of their own. For example, most of the group used chronological approach to set the presentation which actually shows their originality in terms of sharing experience and providing arguments they had made during the process. In other words, the students have 
been able to integrate their presentation time for critical thinking [8] and also reflection stage as the central process of enhancing academic learning [1].

Table 2. Presentation rubrics

\begin{tabular}{|l|l|}
\hline Criteria of evaluation & Description of the criteria \\
\hline $\begin{array}{l}\text { Content (group and } \\
\text { individual) }\end{array}$ & $\begin{array}{l}\text { Relevancy topic to the assignment, organization of presentation } \\
\text { introduction, body and conclusion), extensive indication of research } \\
\text { and information gathering through variaty of sources, examples, data, } \\
\text { etc. }\end{array}$ \\
\hline Delivery & Fluency in speech and transition during handover. \\
\hline Language & $\begin{array}{l}\text { Pronunciation, grammar accuracy, and appropriate vocabularies and } \\
\text { expressions used to convey the message. }\end{array}$ \\
\hline Presentation Aids & $\begin{array}{l}\text { Relevancy aid to the support the message enhancement, degree of } \\
\text { creativity, and language use on the aid. }\end{array}$ \\
\hline $\begin{array}{l}\text { Physical aspect and } \\
\text { personality }\end{array}$ & Confidence, eye contact, and gesture. \\
\hline Handling questions & $\begin{array}{l}\text { Ability to provide relevant answers and attitudes towards questions } \\
\text { and people asking them. }\end{array}$ \\
\hline
\end{tabular}

Furthermore, service learning conducted through the two community projects guided by the mentioned five steps has encouraged the Access students to improve their leadership qualities as service leaders. These include leadership competence (intrapersonal and interpersonal competencies), moral character, caring disposition, self-leadership and continuous self-improvement, and self-reflection [9], of which all of them have been discussed in each step above. Engagement in community based experiential learning activities exposed students to factors and opportunities known to mediate academic achievement, including opportunities for students to act autonomously, develop collegial relationships with adults and peers, and boost their selfesteem and sense of self-efficacy [10]

Last, the students also admitted that community project is a new method applied in their English class and they stated that they were enjoying each step as a fun way to learn English. It means that the students have a positive response to the project in addition to the knowledge and experience they acquired through the project.

\section{Conclusion}

The service learning of two community projects of "helping senior citizens" and "clean the environment campaign" conducted by Access students is found to be effective to enhance the students' English oral skills and leadership qualities as service leaders. There is a positive correlation between experiential based learning and the increasing social awareness and academic enhancement of the development of students' speaking ability in their English class room. The effectiveness is concluded by looking at how the functions of each of the five steps is actually done to achieve the learning goals: developing English performance and fostering social interaction with communities. Not to mention that service learning by conducting community projects is seen as fun new method in learning English by the Access students. 


\section{References}

1. Community Service Center Mary Graydon Center. Faculty guide to service learning [Online] from http://www.american.edu/ocl/volunteer/upload/faculty-guide.pdf (2005). [Accessed on 12 January 2017].

2. A. Meuers. Service-learning \& academic success. [Online] from https://nylc.org/2016/07/06/service-learning-academic-success/ (2016). [Accessed on]

3. K. Farber. Change the world with service learning: how to organize, lead, and assess service-learning projects. Maryland: Rowman \& Littlefield Publishers, Inc. (2011). p. 5. https://eric.ed.gov/?id=ED533225

4. C. Browne, B. Culligan, J. Philips. In focus 2: A vocabulary, reading and critical thinking skills course. Singapore: Cambridge University Press, (2014). pp. 25-32, 5764.

http://assets.cambridge.org/97811076/80074/frontmatter/9781107680074 frontmatter.p $\underline{\mathrm{df}}$

5. C.B. Kaye. The complete guide to service learning: proven, practical ways to engage students in civic responsibility, academic curriculum \& social action. 2nd ed. United States of America: Free Spirit Publishing Inc. (2010). p. 12. https://www.freespirit.com/character-education-leadership-and-servicelearning/complete-guide-to-service-learning-cathryn-berger-kaye/\#

6.Center for Public Service. Planning and implementing a servive-learning course: a guide for faculty members at Gettysburg College second edition [Online] from http://www.gettysburg.edu/about/offices/college life/cps/faculty/links/guide.pdf (2005). [Accessed on 14 January 2017].

7. R. Bringel, J.A. Hatcher. Reflection in service-learning: making meaning of experience. [Online] from https://www.american.edu/ocl/volunteer/upload/Bringle-HatcherReflection.pdf (1999). [Accessed on 10 October 2017]

8. Vanderbilt University. The importance of reflection in service-learning. [Online] from https://www.vanderbilt.edu/oacs/wp-content/uploads/sites/140/The-Importance-ofReflection-in-Service-Learning.doc (2016). [Accessed on 20 October 2017]

9. D.T.L. Shek, H. Leung. Service leadership qualities in university students through the lens of student well-being. In: Promoting service leadership qualities in university students, D.T.L. Shek, H. Leung (Eds). Springer Science+Business Media Singapore, Singapore (2015). pp. 1-16. https://link.springer.com/chapter/10.1007/978-981-287515-0 1. [Accessed on 10 October 2017]

10.A. Furco, S. Root. Phi Delta Kappan, 91, 5:16-20 (2010). http://journals.sagepub.com/doi/abs/10.1177/003172171009100504?journalCode=pdka 